\title{
Brazing of Ti-6Al-4V and Niobium Using Three Silver-Base Braze Alloys
}

\author{
D.W. LIAW and R.K. SHIUE
}

Evaluations of the (infrared)-brazed Ti-6Al-4V and niobium joints using three silver-base braze alloys have been extensively studied. According to the dynamic wetting angle measurement results, the niobium substrate cannot be effectively wetted by all three braze alloys. Because the dissolution of Ti-6Al-4V substrate causes transport of Ti into the molten braze, the molten braze dissolved with $\mathrm{Ti}$ can effectively wet the niobium substrate during brazing. For infrared-brazed Ti-6Al-4V/Ag/Nb joint, it is mainly comprised of the Ag-rich matrix. The TiAg reaction layer is observed at the interface between the braze and Ti-6Al-4V substrate. In contrast, Ti-rich, Ag-rich, and interfacial TiAg phases are found in the furnace-brazed specimen. The dominated Ti-rich phase in the joint is caused by enhanced dissolution between the molten braze and Ti-6Al-4V substrate. The infrared-brazed Ti-6Al$4 \mathrm{~V} / 72 \mathrm{Ag}-28 \mathrm{Cu} / \mathrm{Nb}$ joint is mainly comprised of the $\mathrm{Ag}$-rich matrix and $\mathrm{Ag}-\mathrm{Cu}$ eutectic. With increasing the brazing temperature or time, the amount of $\mathrm{Ag}-\mathrm{Cu}$ eutectic is decreased, and the interfacial $\mathrm{Cu}$-Ti reaction layer(s) is increased. The infrared brazed joint has the highest average shear strength of 224.1 MPa. The averaged shear strength of the brazed joint is decreased with increasing brazing temperature or time, and its fracture location changes from the braze alloy into the interfacial reaction layer(s) due to excessive growth of the $\mathrm{Cu}$-Ti intermetallics. The infrared-brazed Ti-6Al-4V/95Ag$5 \mathrm{Al} / \mathrm{Nb}$ joint is composed of Ag-rich matrix and TiAl interfacial reaction layer. With increasing the brazing time, the amount of Ag-rich phase is greatly decreased, and the interfacial reaction layer becomes $\mathrm{Ti}_{3} \mathrm{Al}$ due to enhanced dissolution of Ti-6Al-4V substrate into the molten braze. The average shear strength of the infrared-brazed joint is $172.8 \mathrm{MPa}$. Additionally, the existence of an interfacial $\mathrm{Ti}_{3} \mathrm{Al}$ reaction layer significantly deteriorates the shear strength of the furnace-brazed specimen.

\section{INTRODUCTION}

TITANIUM alloys are one of the most popular metals for aerospace applications due to their high strength-to-weight ratio, excellent corrosion resistance, and moderate high-temperature strength. ${ }^{[1,2,3]} \mathrm{Ti}-6 \mathrm{Al}-4 \mathrm{~V}$ is a type of $\alpha-\beta$ titanium alloy, which can be strengthened by solution and aging heat treatments. ${ }^{[2]}$ Refractory metals are metals with exceptional high melting points above $2450{ }^{\circ} \mathrm{C} \cdot{ }^{[4]}$ The niobium metal belongs to a type of refractory metals with the melting point of $2468{ }^{\circ} \mathrm{C}$, and it has the lowest density of $8.57 \mathrm{~g} / \mathrm{cm}^{3}$ among all refractory metals. Accordingly, niobium alloys may be selected for their corrosion resistance in chemical and nuclear applications or for their low density and high melting point in aerospace and propulsion applications. ${ }^{[3,4]}$

Joining of dissimilar metals has become increasingly important during the past 2 decades because of the service requirements for structures used in missiles and rockets, supersonic aircraft, nuclear equipment, marine systems, and chemical-processing infrastructure. ${ }^{[5,6,7]}$ The application of brazing Ti-6Al-4V and niobium is possible in production of missiles and rockets. Titanium is considered highly reactive, and it combines readily with oxygen at elevated temperatures. Additionally, titanium becomes embrittled by the inter-

D.W. LIAW, Graduate Student, is with the Department of Materials Science and Engineering, National Dong Hwa University, Hualien 974, Taiwan. R.K. SHIUE, Associate Professor, is with the Department of Materials Science and Engineering, National Taiwan University, Taipei 106, Taiwan. Contact e-mail: rkshiue@ntu.edu.tw

Manuscript submitted May 24, 2004. stitial absorption of oxygen, hydrogen, and nitrogen. Therefore, it must be brazed in a vacuum or dry inert-gas atmosphere. ${ }^{[6]} \mathrm{Ti}-6 \mathrm{Al}-4 \mathrm{~V}$ is usually fabricated to obtain fine-grain equiaxed duplex microstructure to produce maximum ductility. It is desirable to maintain this microstructure by requiring that the brazing temperature does not exceed the beta-phase transformation temperature, which varies from $900{ }^{\circ} \mathrm{C}$ to $1040{ }^{\circ} \mathrm{C}^{[6]}$ Additionally, it is widely reported that titanium also reacts to form brittle intermetallics with many other metals, e.g., $\mathrm{Ni}, \mathrm{Al}$, and $\mathrm{Cu}^{[6,8-15]}$ Filler metals with high content of such elements should be avoided in brazing titanium and its alloys.

Silver-based braze alloys are featured with low melting points, and they have been successfully applied in brazing Ti6Al-4V and TZM alloy in the previous studies. ${ }^{[16,17,18]}$ Accordingly, it is possible to braze Ti-6Al-4V and niobium metal using the silver-base braze alloy. As discussed earlier, it is highly preferred that the brazing temperature of Ti-6Al-4V alloy is below its $\beta$ transus temperature. The melting point of pure silver is $961{ }^{\circ} \mathrm{C}$, which exceeds the $\beta$ transus temperature of the Ti-6Al-4V alloy. ${ }^{[4,16]}$ It was chosen in the experiment for comparison purposes. In contrast, the liquidus temperatures of $78 \mathrm{Ag}-28 \mathrm{Cu}$ and $95 \mathrm{Ag}-5 \mathrm{Al}$ in weight percent are as low as $780^{\circ} \mathrm{C}$ and $810^{\circ} \mathrm{C}$, respectively. ${ }^{[17,18]} \mathrm{Con}-$ sequently, they are suitable in brazing Ti-6Al-4V and niobium.

The development of high-intensity quartz lamps and the availability of suitable reflectors have made infrared heating an important generator of heat for brazing ${ }^{[5]}$ Infrared heating is a way of rapidly heating the joint by infrared rays generated from the heated tungsten filament in the quartz lamp. ${ }^{[12]}$ Compared with the conventional furnace brazing, infrared brazing is 
featured with a rapid heating rate as high as $3000{ }^{\circ} \mathrm{C} / \mathrm{min} .{ }^{[12,19-21]}$ Decreasing the brazing temperature or time is usually preferred in order to achieve desired properties of the joint, e.g., decreased interfacial reactions, erosion of both substrates, and contaminations. ${ }^{[16-18,22,23]}$ Accordingly, infrared brazing is a highly potential process in joining dissimilar materials.

The purpose of this investigation is concentrated on vacuum brazing of Ti-6Al-4V and niobium using three silverbase braze alloys for low and medium temperature applications. The wettability of braze alloy on the substrate, microstructural evolution, and shear strength of the brazed joint are experimentally evaluated.

\section{EXPERIMENTAL PROCEDURES}

The base metal used in the experiments was Ti-6Al-4V plate with the dimension of $10 \times 10 \times 3 \mathrm{~mm}$. The chemical composition of Ti-6Al-4V substrate in weight percent was $5.76 \mathrm{Al}$, $4.03 \mathrm{~V}, 0.28 \mathrm{Fe}, 0.06 \mathrm{C}$, and balance Ti. The pure niobium substrate was in the form of disks with 25-mm diameter and 3-mm thickness. Both substrates were polished with $\mathrm{SiC}$ papers, and subsequently cleaned using an ultrasonic bath with acetone as solvent prior to brazing. Pure silver, $72 \mathrm{Ag}-28 \mathrm{Cu}$, and $95 \mathrm{Ag}-$ $5 \mathrm{Al}$ in weight percent were selected as the brazing filler metals. They are in the form of foils with the thickness of $50 \mu \mathrm{m}$ and width of $50 \mathrm{~mm}$ throughout the experiments. Based on the AgTi binary alloy phase diagram, the melting point of Ag alloy is not significantly affected by the Ti addition up to 2 wt pct, and the liquidus temperatures of the Ag-based alloys are increased with increasing the Ti content above 2 wt pct. ${ }^{[2]}$ The melting ranges of these braze alloys are shown in Table I.

The dynamic wetting angle measurements were performed using a conventional vacuum furnace with the temperature range between $800{ }^{\circ} \mathrm{C}$ and $1000{ }^{\circ} \mathrm{C}$ for 0 to 1800 seconds. ${ }^{[23]}$ The heating rate of the furnace was set at $30{ }^{\circ} \mathrm{C} / \mathrm{min}$. The braze alloy with near spherical shape used in the dynamic wetting angle test was prepared from the braze alloy foils by vacuum arc remelting with the operation voltage of $60 \mathrm{~V}$ and the current of 130 to $150 \mathrm{~A}$. The weight of each spherical ball was approximately $0.12 \mathrm{~g} .{ }^{[22,23]}$ The spherical braze alloy was placed on the niobium substrate, and the image of the molten braze on the substrate was recorded simultaneously by using a digital camera during the wetting angle measurement. The wettability experiments for Ag-based alloys were performed at 1000 ${ }^{\circ} \mathrm{C}$. For Ag-Cu-based braze alloys, wettability experiments are performed at $800{ }^{\circ} \mathrm{C}$ and $850{ }^{\circ} \mathrm{C}$, respectively. For Ag-Al-based braze alloys, wettability experiments are performed at $850{ }^{\circ} \mathrm{C}$,

Table I. Summary of the Process Variables Used in the Experiment

\begin{tabular}{lrrr}
\hline $\begin{array}{l}\text { Composition } \\
\text { of Braze Alloys } \\
\text { (Wt Pct) }\end{array}$ & $100 \mathrm{Ag}$ & $72 \mathrm{Ag}-28 \mathrm{Cu}$ & $95 \mathrm{Ag}-5 \mathrm{Al}$ \\
\hline $\begin{array}{l}\text { Solidus/liquidus } \\
\quad \text { temperature }\left({ }^{\circ} \mathrm{C}\right)\end{array}$ & $961 / 961$ & $780 / 780$ & $780 / 810$ \\
$\begin{array}{l}\text { Furnace brazing } \\
\text { temperature }\left({ }^{\circ} \mathrm{C}\right)\end{array}$ & 1000,1050 & 800,850 & 850,900 \\
$\begin{array}{l}\text { Furnace brazing time }(\mathrm{s}) \\
\text { Infrared brazing }\end{array}$ & 600,1200 & 600,1200 & 600,1200 \\
$\quad$ temperature $\left({ }^{\circ} \mathrm{C}\right)$ & 1000 & 850 & 950 \\
Infrared brazing time $(\mathrm{s})$ & 60 & 60 & 60 \\
\hline
\end{tabular}

$900{ }^{\circ} \mathrm{C}$, and $950^{\circ} \mathrm{C}$. Accordingly, selected temperatures of wettability tests are consistent with those of brazing experiments.

Both furnace and infrared vacuum brazing were performed in the experiment. Furnace brazing was tested in a vacuum of $5 \times 10^{-5}$ mbar at temperatures between $800^{\circ} \mathrm{C}$ and $1050{ }^{\circ} \mathrm{C}$ for various time periods, and its heating rate was kept at $30^{\circ} \mathrm{C} /$ min. Infrared brazing was made in a vacuum of $5 \times 10^{-5}$ mbar between $850{ }^{\circ} \mathrm{C}$ and $1000{ }^{\circ} \mathrm{C}$ for 60 seconds. The heating rate of infrared brazing was kept at $600{ }^{\circ} \mathrm{C} / \mathrm{min}$ throughout the experiment. Additionally, both infrared and furnace-brazed specimens were preheated at $600{ }^{\circ} \mathrm{C}$ for 600 seconds before the brazing temperature was reached.

The heating rate basically has little effect on the brazing operation if the braze alloy has a narrow melting range between solidus and liquidus temperatures. For the brazing filler alloy with a wide range of solidus and liquidus temperatures, the composition of the melt will gradually change as the temperature increases from the solidus to liquidus. If the portion that melts first is allowed to flow out, the remaining solid may not melt and may retain behind as a residue, which is called liquation. ${ }^{[5]}$ Accordingly, a filler metal with a wide melting range needs rapid heating cycles to minimize separation during brazing. ${ }^{[25]}$ Table I summarizes all brazing process variables used in the experiment.

The brazed specimen was cut by a low-speed diamond saw, and subsequently processed by a standard metallographic procedure prior to inspection. The cross section of the brazed specimens was examined using a HITACHI* $3500 \mathrm{H}$

*HITACHI is a trademark of Hitachi, Ltd., Tokyo, Japan.

scanning electron microscope (SEM) with an accelerating voltage of $15 \mathrm{kV}$. Quantitatively, chemical analysis was performed using a JEOL* JXL-8800M electron probe micro-

*JEOL is a trademark of Japan Electron Optics Ltd., Tokyo.

analyzer (EPMA) with an operation voltage of $20 \mathrm{kV}$ and spot size of $1 \mu \mathrm{m}$.

Shear tests were performed in order to evaluate the bonding strength of selected brazed specimens. ${ }^{[12,21,22]}$ A Shimadzu AG-10 universal testing machine with a constant speed of $0.5 \mathrm{~mm} / \mathrm{min}$ compressed the brazed specimens. The fractured surfaces after shear tests were examined by using an SEM. After the shear test, the brazed specimen was fractured into Ti-6Al-4V and $\mathrm{Nb}$ pieces. Because the brazed joint was fractured roughly along the braze alloy, the fractured surface of the Ti-6Al-4V piece was further analyzed using an X-ray diffractometer. A Rigaku RINT 2100 X-ray diffractometer was applied for structure analysis, and the $\mathrm{Cu} K_{a}$ was chosen as the X-ray source. The X-ray scan rate was set at $4 \mathrm{deg} / \mathrm{min}$, and its range was between 25 and $90 \mathrm{deg}$. The X-ray diffraction pattern was recorded and identified using the Powder Diffraction File data bank. Finally, the cross sections of the above fractured specimens are mounted in an epoxy, and examined by an SEM in order to locate the crack site of the brazed joint.

\section{RESULTS AND DISCUSSION}

\section{A. Ti-6Al-4V/Ag/Nb Brazed Joint}

According to the previous study, the molten silver can effectively wet Ti-6Al-4V substrate at $1000{ }^{\circ} \mathrm{C}$ for 1200 seconds, 
and complete spreading of the molten silver on the Ti-6Al-4V substrate at $1050{ }^{\circ} \mathrm{C}$ for 150 seconds. ${ }^{[16]}$ Figure 1 shows the dynamic wetting angle measurements of pure $\mathrm{Ag}$ and 97.6Ag-2.4Ti (wt pct) on the niobium substrate at $1000{ }^{\circ} \mathrm{C}$ for 0 to 1800 seconds, respectively. Based on the figure, the molten silver braze cannot effectively wet the niobium substrate, and its wetting angle is as high as $110 \mathrm{deg}$, even increasing the time period to 1800 seconds. In contrast, the wetting angle of the molten 97.6Ag-2.4Ti (wt pct) braze on the niobium substrate is drastically decreased to $25 \mathrm{deg}$ at $1000{ }^{\circ} \mathrm{C}$ for 1800 seconds. It is obvious that minor addition of $2.4 \mathrm{wt}$ pct $\mathrm{Ti}$ into the silver braze can greatly improve its wettability on the niobium substrate.

According to the Ag- $\mathrm{Nb}$ binary alloy phase diagram, the solubility of $\mathrm{Nb}$ substrates in molten silver is extremely low, and no intermediate compound has been reported for the Ag$\mathrm{Nb}$ system. ${ }^{[24]}$ In contrast, the niobium substrate and $\beta \mathrm{Ti}$ are completely miscible, and there is no intermediate compound in the $\mathrm{Nb}$-Ti binary phase diagram. ${ }^{[24]}$ The dissolution of Ti$6 \mathrm{Al}-4 \mathrm{~V}$ substrate into the molten braze primarily dominates

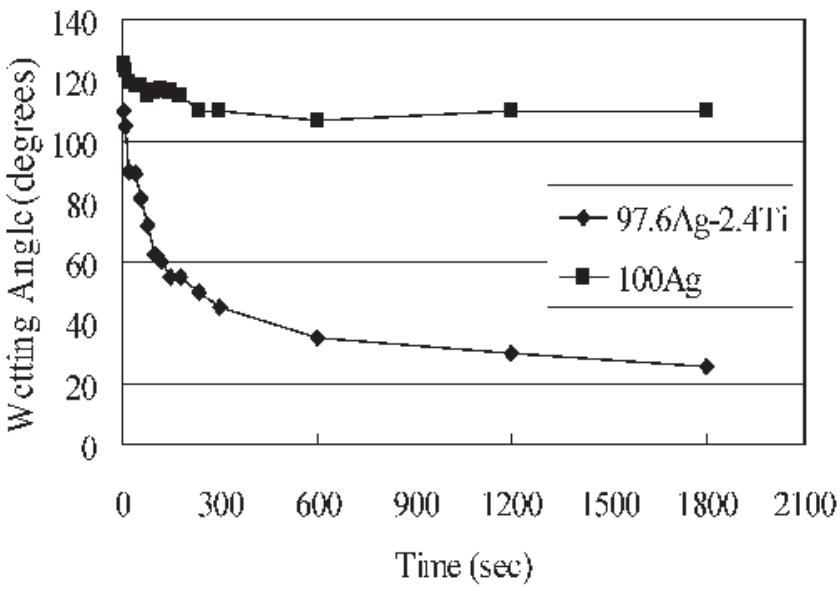

Fig. 1-The dynamic wetting angle measurements of pure $\mathrm{Ag}$ and 97.6Ag2.4Ti (wt pct) on the niobium substrate at $1000{ }^{\circ} \mathrm{C}$ for 0 to $1800 \mathrm{~s}$. the mass transport of Ti into braze during brazing. For the thin layer of molten braze, the effect of gravity or thermosolute convection is much less than that of interfacial surface tension determined by wetting angle measurements of the molten braze on the substrate. ${ }^{[7]}$ Because the molten silver-rich braze dissolves little niobium, it is expected that high wetting angle is observed for the pure molten silver on the niobium substrate, as demonstrated in Figure 1 . In contrast, the $\beta$-Ti is completely miscible with the niobium substrate. Accordingly, the addition of minor Ti into the silver-rich braze alloy can greatly improve its wettability on the substrate due to the niobium alloyed with minor Ti during the wetting angle test (Figure 1). Consequently, it is reasonable to conclude that wettability of the silver-base braze alloy on the $\mathrm{Nb}$ substrate can be greatly improved with the addition of minor Ti. The dissolution of Ti-6Al-4V substrate during brazing may result in mass transport of Ti into the molten silver, and the niobium substrate alloyed with $\mathrm{Ti}$ from the molten braze is driven by the concentration gradient of $\mathrm{Ti}$ in the molten braze and niobium substrate. Accordingly, the Ag-rich braze alloyed with Ti can easily wet the niobium substrate in the experiment. It is further demonstrated in the following chemical analysis experiments.

In the case of infrared heating, there may be temperature gradients in the system. However, thermal conductivities of metals are high as compared with those of many other nonmetals. It is expected that the initial transient temperature profile of the infrared brazed specimen will quickly approach equilibrium. Additionally, the mass transfer in the brazed joint is not prominent until the braze alloy melts due to slow solidstate interdiffusion. Therefore, both brazing temperature and time dominate the mass transfer during brazing. The initial transient temperature gradient in the specimen caused by infrared brazing places little effect on the mass transfer of brazed joint.

Figure 2 shows the SEM secondary electron image (SEI), backscattered electron image (BEI), and EPMA chemical analysis results of the infrared-brazed Ti-6Al-4V/Ag/Nb joint at $1000{ }^{\circ} \mathrm{C}$ for 60 seconds. The infrared-brazed joint is mainly comprised of the Ag-rich phase, as marked by "B" in Figure 2. The TiAg reaction layer at the interface between the braze
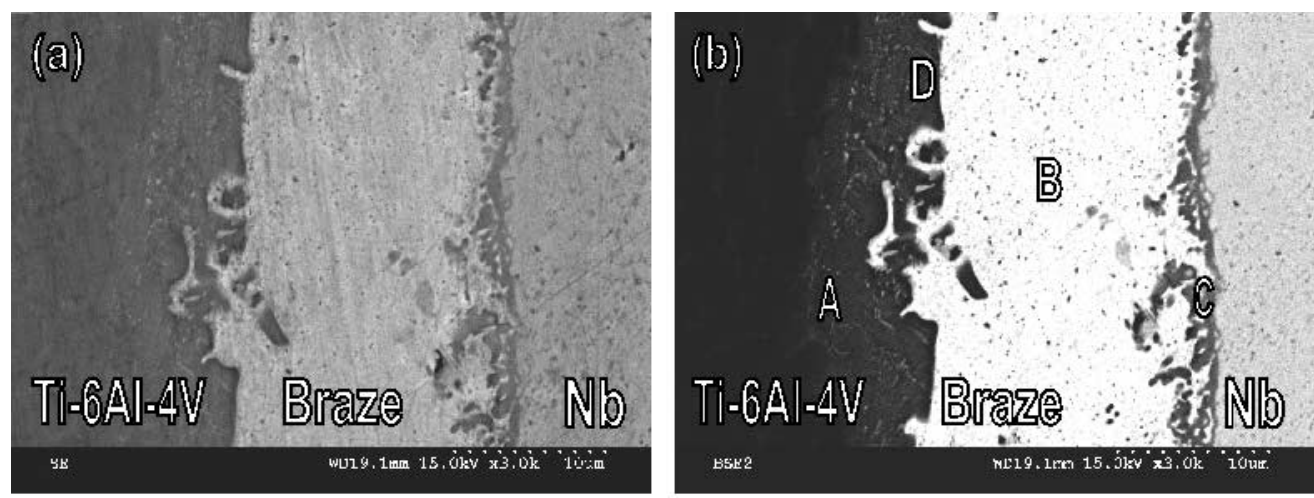

\begin{tabular}{cccccc}
\hline Location (phasc) / a1\% & $\mathrm{Ti}$ & $\Lambda \mathrm{g}$ & $\Lambda 1$ & $\mathrm{~V}$ & $\mathrm{Nb}$ \\
\hline $\mathrm{A}$ ('i-rich) & 81.8 & 8.1 & 7.3 & 2.7 & 0.0 \\
$\mathrm{~B}$ (Ag-rich) & 0.4 & 96.5 & 3.1 & 0.0 & 0.0 \\
C (Ti-rich) & 71.8 & 3.6 & 8.0 & 0.3 & 16.3 \\
D (TiAg) & 41.6 & 51.5 & 4.9 & 2.1 & 0.0 \\
\hline
\end{tabular}

Fig. 2-The SEM (a) SEI, (b) BEI, and EPMA chemical analysis results of the infrared-brazed Ti-6Al-4V/Ag/Nb joint at $1000{ }^{\circ} \mathrm{C}$ for $60 \mathrm{~s}$. 
and Ti-6Al-4V substrate is observed, as marked by " $\mathrm{D}$ " in the figure. Additionally, it is observed that there is a Ti-rich phase alloyed with $\mathrm{Nb}$ between the braze and $\mathrm{Nb}$ substrate, as marked by "C" in Figure 2. It is in accordance with the previous discussion. The dissolution of Ti-6Al-4V substrate results in Ti transport into the molten braze, so the Ag-rich braze alloyed with Ti can readily wet the niobium substrate during brazing.

Based on the Ag-Ti binary alloy phase diagram, the solubility of $\mathrm{Ti}$ in $\mathrm{Ag}$ is about 2 wt pet at $960{ }^{\circ} \mathrm{C}$ and 1 wt pet at room temperature, respectively. ${ }^{[24]}$ Additionally, there is a eutectic reaction right away to form $\mathrm{Ag}$ and $\mathrm{TiAg}$ compounds. Both interfacial TiAg and Ag-rich phases are observed in the SEM observations, as shown in Figure 2. The Ag-rich phase is alloyed with minor Ti. The formation of interfacial TiAg phase results in retarding the transport of $\mathrm{Ti}$ from the Ti-6Al-4V substrate into the molten Ag-rich braze, so the eutectic TiAg and Agrich phases are not observed in the figure. However, there are some black spots in the Ag-rich matrix, as displayed in Figure 2(b). Precipitates found in the Ag-rich matrix are primarily caused by decreased solubility of $\mathrm{Ti}$ in the Ag-rich phase after brazing. However, they cannot be accurately analyzed by EPMA due to their sizes being much lower than $1 \mu \mathrm{m}$.

Figure 3 shows SEM images of the furnace-brazed specimen for various brazing conditions. The microstructure of
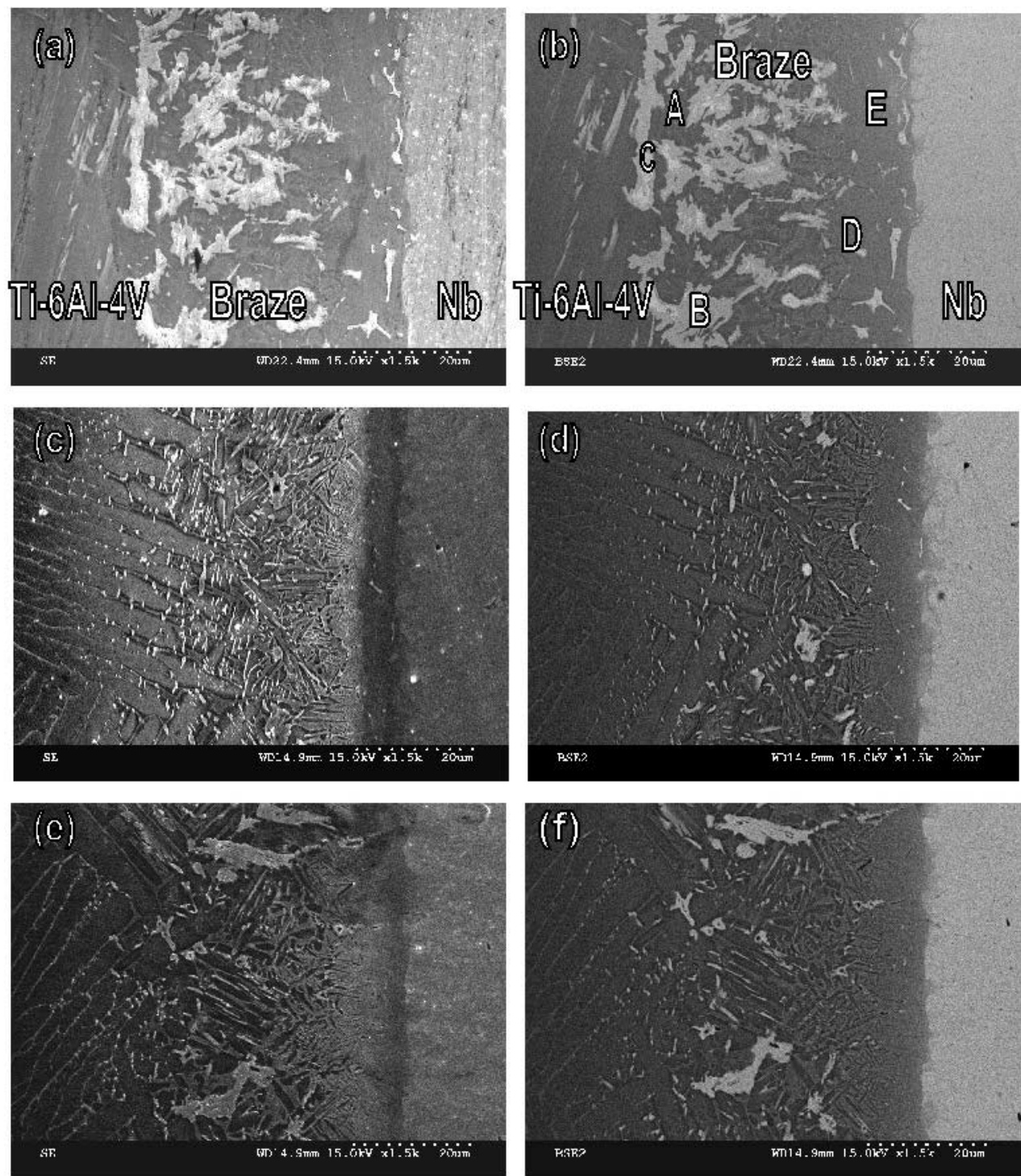

\begin{tabular}{cccccc}
\hline Location (phasc) $/ \mathrm{al} \%$ & $\mathrm{Ti}$ & $\mathrm{Ag}$ & $\mathrm{Al}$ & $\mathrm{V}$ & $\mathrm{Nb}$ \\
\hline A (Ti-rich) & 82.8 & 6.1 & 9.5 & 0.8 & 0.8 \\
B (TiAg) & 49.7 & 49.3 & 0.5 & 0.3 & 0.2 \\
C (Ag-rich) & 29.9 & 69.5 & 0.4 & 0.2 & 0.1 \\
D (li-rich) & 68.7 & 3.5 & 7.7 & 0.4 & 19.7 \\
E. (li-rich) & 67.3 & 3.5 & 7.3 & 0.4 & 21.5 \\
\hline
\end{tabular}

Fig. 3-The SEM images and EPMA chemical analysis results of the furnace-brazed specimens: $(a)$ SEI, $(b)$ BEI $\left(1000{ }^{\circ} \mathrm{C} \times 600 \mathrm{~s}\right),(c)$ SEI, $(d)$ BEI $\left(1000{ }^{\circ} \mathrm{C} \times 1200 \mathrm{~s}\right),(e) \mathrm{SEI}$, and $(f) \mathrm{BEI}\left(1050{ }^{\circ} \mathrm{C} \times 600 \mathrm{~s}\right)$. 
the furnace-brazed joint is different from that of the infraredbrazed one. The dissolution of Ti-6Al-4V substrate during infrared brazing is minimized due to its rapid thermal cycle. In contrast, both dissolution of the Ti-6Al-4V into the molten braze and diffusion of the braze alloy into the substrates are greatly enhanced for all furnace-brazed specimens. Ti-rich (marked by A, D, and E), Ag-rich (marked by C), and TiAg (marked by B) phases are observed in Figure 3. With increasing the brazing temperature or time, the Ag-rich phase is dissolved into Ti-6Al-4V substrate, and results in decreasing the amount of both TiAg and Ag-rich phases in the brazed joint. Accordingly, the Ti-rich phase dominates the microstructure of all furnace-brazed specimens, as illustrated in Figure 3.

The brazing process is technically different from the transient-liquid-phase (TLP) bonding process. ${ }^{[5,6,7]}$ The TLP bonding process usually contains a homogenization stage resulting in a chemically homogeneous joint. For the TLP bonding process, the chemical composition of the filler metal must be carefully selected in order to avoid formation of brittle stable intermetallic phase(s) in the joint. In contrast, the brazing process lacks the homogenization stage of the brazed joint. The filler metal is not necessarily isothermally solidified during brazing. The dissolution of the base metal into the molten braze may simultaneously lead to both isothermal solidification of the molten braze and erosion of the base metal. However, excessive erosion of the base metal and formation of brittle phase(s) in the brazing process should be avoided in order to obtain a sound brazed joint. Therefore, it is expected that the rapid infrared brazed joint performs better than the furnace-brazed joint due to its fast thermal history.

Table II displays the shear strength of all brazed specimens. The average shear strength of the infrared-brazed Ti$6 \mathrm{Al}-4 \mathrm{~V} / \mathrm{Ag} / \mathrm{Nb}$ joint is $173.0 \mathrm{MPa}$, and it is much higher than that of the furnace-brazed specimen (117.5 MPa). Figure 4 displays the SEM cross section of the Ti-6Al-4V/Ag/Nb joint after shear test. For the infrared-brazed specimen, the crack propagates along the Ag-rich matrix in the brazed joint (Figure 4(a)). In contrast, the furnace-brazed specimen is fractured primarily along the Ti-rich phase (Figure 4(b)). Based on the experimental observation, the presence of the Ti-rich phase in the furnace-brazed specimen deteriorates its joint strength.

Table II. Shear Strengths of All Brazed Specimens

\begin{tabular}{|c|c|c|c|c|c|}
\hline Braze Alloy (Wt Pct) & Brazing Type & Temperature $\left({ }^{\circ} \mathrm{C}\right)$ & Time (s) & Shear Strength (MPa) & Average Shear Strength (MPa) \\
\hline \multirow[t]{4}{*}{$100 \mathrm{Ag}$} & infrared & 1000 & 60 & 174.0 & 173.0 \\
\hline & infrared & 1000 & 60 & 172.0 & \\
\hline & furnace & 1000 & 1200 & 124.2 & 117.5 \\
\hline & furnace & 1000 & 1200 & 110.7 & \\
\hline \multirow[t]{10}{*}{$72 \mathrm{Ag}-28 \mathrm{Cu}$} & infrared & 850 & 60 & 212.9 & 224.1 \\
\hline & infrared & 850 & 60 & 235.3 & \\
\hline & furnace & 800 & 600 & 159.6 & 164.5 \\
\hline & furnace & 800 & 600 & 169.3 & \\
\hline & furnace & 800 & 1200 & 136.0 & 142.4 \\
\hline & furnace & 800 & 1200 & 148.8 & \\
\hline & furnace & 850 & 600 & 120.1 & 130.3 \\
\hline & furnace & 850 & 600 & 140.4 & \\
\hline & furnace & 850 & 1200 & 117.4 & 108.7 \\
\hline & furnace & 850 & 1200 & 100.0 & \\
\hline \multirow[t]{4}{*}{$95 \mathrm{Ag}-5 \mathrm{Al}$} & infrared & 950 & 60 & 174.7 & 172.8 \\
\hline & infrared & 950 & 60 & 170.9 & \\
\hline & furnace & 900 & 1200 & - & - \\
\hline & furnace & 900 & 1200 & - & \\
\hline
\end{tabular}
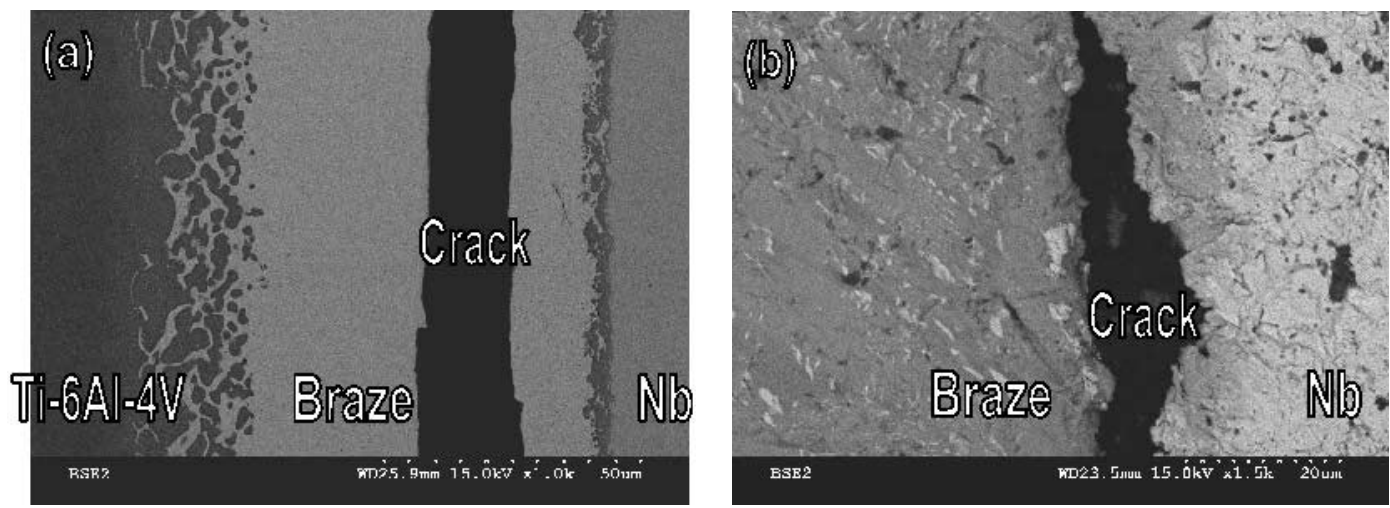

Fig. 4-SEM cross section of Ti-6Al-4V/Ag/Nb joint after shear test: $(a) \mathrm{BEI}, 1000^{\circ} \mathrm{C} \times 60 \mathrm{~s}$ (infrared brazing) and $(b) \mathrm{BEI}, 1000{ }^{\circ} \mathrm{C} \times 1200 \mathrm{~s}($ furnace brazing). 

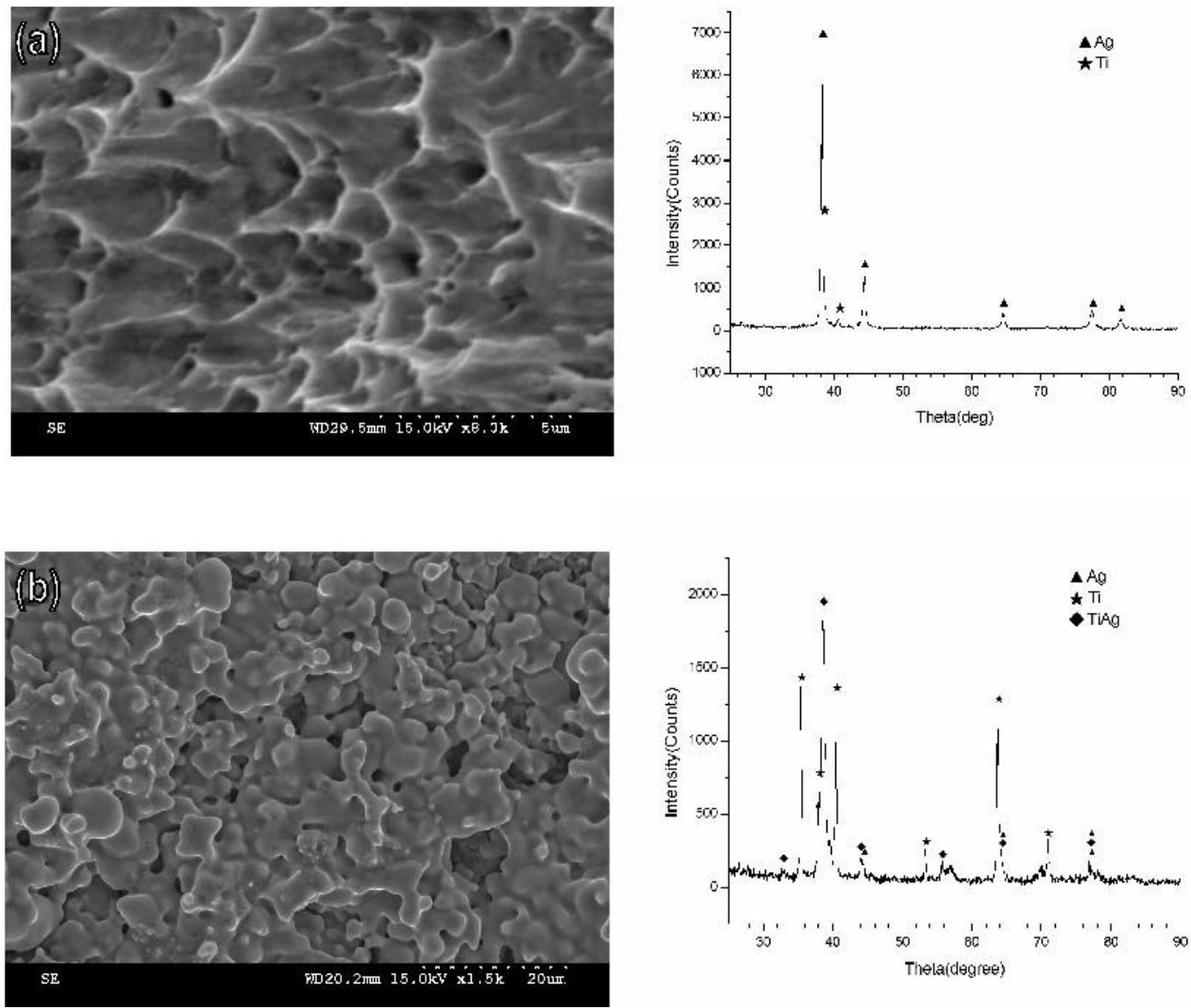

Fig. 5-SEM fractographs and X-ray analysis of Ti-6Al-4V/Ag/Nb joint after shear test: (a) $1000{ }^{\circ} \mathrm{C} \times 60 \mathrm{~s}$ (infrared brazing) and $(b) 1000{ }^{\circ} \mathrm{C} \times 1200 \mathrm{~s}$ (furnace brazing).

Figure 5 shows the SEM fractographs and X-ray analysis of the Ti-6Al-4V/Ag/Nb joint after shear test. The dimple-dominated fractured surface is widely observed for the infraredbrazed specimen, and the major X-ray characteristic peaks of $\mathrm{Ag}$ are also obtained in Figure 5(a). Because the crack is primarily located at the Ag-rich matrix of the infrared-brazed joint, as illustrated in Figure 4(a), the dimple-dominated fractured surface is consistent with the microstructural observation.

The fractograph of the furnace-brazed specimen (Figure 5(b)) is very different from that of the infrared-brazed specimen (Figure 5(a)). Characteristic peaks of Ti, Ag, and TiAg are all identified from the X-ray structural analysis of the fractured surfaces, and it is in accordance with the previous EPMA chemical analysis results. Additionally, the dendritic morphology with solidification defects is also extensively observed in Figure 5(b). For the infrared-brazed specimen, the crack propagates along the Ag-rich matrix. In contrast, the furnacebrazed specimen is fractured primarily along the Ti-rich phase. The dominated Ti-rich phase in the joint is caused by enhanced dissolution between the molten braze and Ti-6Al-4V substrate. The average shear strength of the furnace-brazed joint is significantly deteriorated by the existence of shrinkage porosity.

\section{B. Ti-6Al-4V/72Ag-28Cu/Nb-Brazed Joint}

According to the previous study, the $\mathrm{Ag}-\mathrm{Cu}$ eutectic braze can effectively wet Ti-6Al-4V substrate at $850{ }^{\circ} \mathrm{C}$ for 600 seconds, and complete spreading of the molten braze on

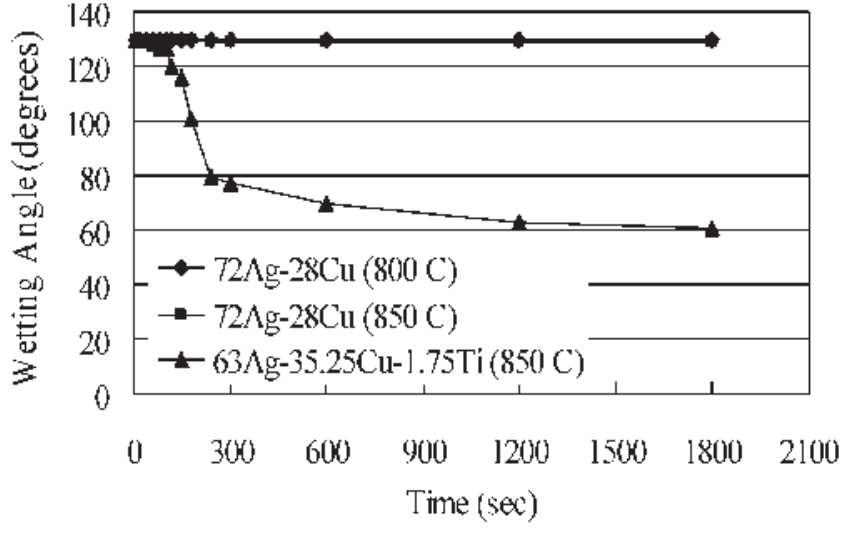

Fig. 6-The dynamic wetting angle measurements of $72 \mathrm{Ag}-28 \mathrm{Cu}$ and $63 \mathrm{Ag}-$ $35.25 \mathrm{Cu}-1.75 \mathrm{Ti}$ brazes on the niobium substrate at $800{ }^{\circ} \mathrm{C}$ and $850{ }^{\circ} \mathrm{C}$ for 0 to $1800 \mathrm{~s}$.

the Ti-6Al-4V plate is achieved at $850{ }^{\circ} \mathrm{C}$ for $1200 \mathrm{sec}-$ onds. ${ }^{[17]}$ Figure 6 shows the dynamic wetting angle measurements of both $72 \mathrm{Ag}-28 \mathrm{Cu}$ and $68.8 \mathrm{Ag}-26.7 \mathrm{Cu}-4.5 \mathrm{Ti}$ on the niobium substrate for $800{ }^{\circ} \mathrm{C}$ and $850{ }^{\circ} \mathrm{C}$ between 0 and 1800 seconds, respectively. It is noted that poor wettability of the molten $\mathrm{Ag}-\mathrm{Cu}$ eutectic braze on the niobium metal is observed for temperatures below $850{ }^{\circ} \mathrm{C}$. Both $\mathrm{Ag}$ and $\mathrm{Cu}$ are completely insoluble with the $\mathrm{Nb}$ substrate, and there is no intermediate compound available for $\mathrm{Ag}-\mathrm{Nb}$ and $\mathrm{Cu}-$ $\mathrm{Nb}$ systems. ${ }^{[24]}$ In contrast, excellent wetting of the niobium 
substrate is observed for the molten $63 \mathrm{Ag}-35.25 \mathrm{Cu}-1.75 \mathrm{Ti}$ (wt pct) alloy. With minor addition of active ingredient (Ti) into Ag-Cu braze, its wettability on the $\mathrm{Nb}$ substrate is significantly increased. Accordingly, dissolution of Ti-6Al$4 \mathrm{~V}$ substrate into the molten braze during brazing can readily improve the wettability of $72 \mathrm{Ag}-28 \mathrm{Cu}$ braze on the niobium substrate.

Figure 7 shows the SEM images and EPMA chemical analysis results of the infrared-brazed Ti-6Al-4V/72Ag$28 \mathrm{Cu} / \mathrm{Nb}$ joint at $850{ }^{\circ} \mathrm{C}$ for 60 seconds. Based on the isothermal section of $\mathrm{Ag}-\mathrm{Cu}-\mathrm{Ti}$ ternary alloy phase diagrams at $700{ }^{\circ} \mathrm{C}, \mathrm{Ti}_{3} \mathrm{Cu}_{4}, \mathrm{TiCu}$, and Ag-rich phases form the composition triangle. ${ }^{[17,25]}$ This demonstrates that the Ti preferentially interacts with the $\mathrm{Cu}$ instead of $\mathrm{Ag}$ from the molten braze. According to the EPMA chemical analysis results, the $\mathrm{Ti}$ interacts with the $\mathrm{Cu}$, and forms $\mathrm{Ti}_{3} \mathrm{Cu}_{4}$ interfacial reaction layer, as marked by "C" (Figure 7). The continuous $\mathrm{Ti}_{3} \mathrm{Cu}_{4}$ interfacial reaction layer has a thickness of approximately $3 \mu \mathrm{m}$. Additionally, the depletion of copper from the molten braze results in braze alloy composition deviating from $\mathrm{Ag}-\mathrm{Cu}$ eutectic toward the Ag-rich composition. ${ }^{[17]}$ Consequently, the infrared-brazed joint mainly consists of primary Ag-rich phase (marked by B) and Ag-Cu eutectic.

Figure 8 shows SEM images and EPMA chemical analysis results of the furnace-brazed specimen at $800{ }^{\circ} \mathrm{C}$ for 600 and 1200 seconds. With increasing brazing temperature or time, the interfacial reaction is greatly enhanced. There are two interfacial reaction layers identified in the figure. Their stoichiometric ratios between $\mathrm{Ti}$ and $\mathrm{Cu}$ are close to $\mathrm{TiCu}$ (point $\mathrm{A}$ in Figure $8(\mathrm{~d})$ ) and $\mathrm{Ti}_{3} \mathrm{Cu}_{4}$ (points $\mathrm{B}$ and $\mathrm{C}$ in Figure $8(\mathrm{~d})$ ), respectively. This is similar to a previous study on brazing Ti-6Al-4V and TZM alloy using the $72 \mathrm{Ag}-28 \mathrm{Cu}$ braze alloy. ${ }^{[17]}$

Figure 9 shows SEM images and EPMA chemical analysis results of the furnace-brazed specimens. Similar to the aforementioned result, the growth of the $\mathrm{TiCu}$ interfacial reaction layer results in depletion of the copper content from the molten braze. Therefore, the Ag-Cu eutectic is consumed from the brazed joint, and the Ag-rich matrix dominates the brazed joint, as illustrated in Figures 9(b) and (d). With increasing the brazing temperature to $850{ }^{\circ} \mathrm{C}$, the thickness of the $\mathrm{TiCu}$ reaction layer is increased to about $10 \mu \mathrm{m}$, as shown in Figure 9(d). It is noted that the copper contents in the $\mathrm{Ag}-\mathrm{Cu}$ eutectic braze are consumed due to formation of interfacial $\mathrm{Cu}-\mathrm{Ti}$ intermetallics. Therefore, the eutectic microstructure can only be obtained from the infrared-brazed specimen due to its rapid thermal cycle, as illustrated in Figure 7. In contrast, the eutectic microstructure is not obvious for all furnace-brazed specimens (Figures 8 and 9), especially for the specimen furnace brazed at $850{ }^{\circ} \mathrm{C}$ for 1200 seconds.

According to the experimental results, the application of the infrared brazing cannot completely avoid the formation of interfacial reaction layer(s). However, it provides an effective way to inhibit excessive growth of interfacial reaction layer(s). Additionally, it is also noted that the interfacial $\mathrm{Ti}_{2} \mathrm{Cu}$ phase is observed in the furnace-brazed specimen, as marked by $\mathrm{A}$ in Figure 9(b). According to the $\mathrm{Cu}$-Ti binary alloy phase diagram, there are no other phases except $\mathrm{Ti}_{2} \mathrm{Cu}$ between $\mathrm{Ti}$ and $\mathrm{TiCu} .{ }^{[24]} \mathrm{It}$ is reasonable to conclude that the $\mathrm{Ti}_{2} \mathrm{Cu}$ phase with the smooth interface results from interdiffusion between $\mathrm{TiCu}$ and $\mathrm{Ti}-6 \mathrm{Al}-4 \mathrm{~V}$ substrate. ${ }^{[17]}$

Table II lists the shear strength of all brazed Ti-6Al$4 \mathrm{~V} / 72 \mathrm{Ag}-28 \mathrm{Cu} / \mathrm{Nb}$ joints. According to Table II, the infraredbrazed specimen demonstrates the highest average shear strength up to 224.1 MPa among all specimens. The averaged shear strength of brazed Ti-6Al-4V/72Ag-28Cu/Nb joint is decreased with increasing brazing temperature or time. The specimen furnace brazed at $850{ }^{\circ} \mathrm{C}$ for 1200 seconds demonstrates the lowest shear strength, 108.7 MPa.

Figure 10 displays the SEM cross section of Ti-6Al$4 \mathrm{~V} / 72 \mathrm{Ag}-28 \mathrm{Cu} / \mathrm{Nb}$ joint after shear test. The crack location of the brazed joint is also indicated in the figure. There are interesting results with reference to deformation of the brazed layer. For example, the eutectic in the infrared-brazed specimen has different morphology, and it shows extensive deformation compared to those of furnace-brazed specimens. For the infrared-brazed specimen, the crack propagates along the Ag-Cu eutectic braze (Figure 10(a)). Additionally, the
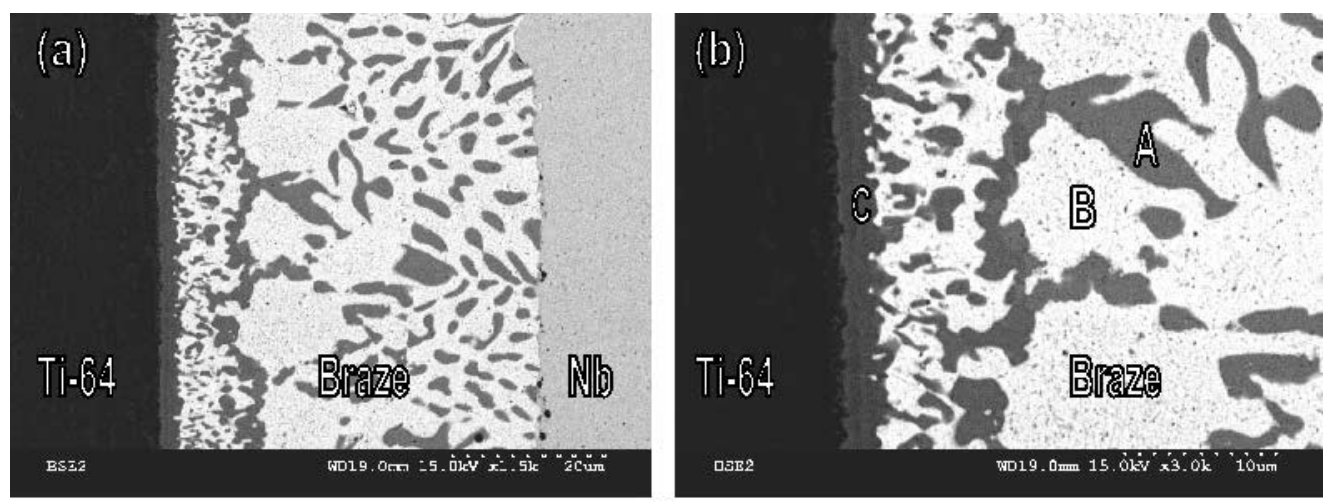

\begin{tabular}{ccccccc}
\hline Location (phase) $/$ at $\%$ & $\mathrm{Ti}$ & $\mathrm{Ag}$ & $\mathrm{Cu}$ & $\mathrm{Al}$ & $\mathrm{V}$ & $\mathrm{Nb}$ \\
\hline $\mathrm{A}(\mathrm{Cu}$-rich) & 1.3 & 4.4 & 92.9 & 1.4 & 0.0 & 0.0 \\
$\mathrm{~B}(\mathrm{Ag}-$-rich) & 0.3 & 86.3 & 11.4 & 1.9 & 0.0 & 0.0 \\
$\mathrm{C}\left(\mathrm{Ti}_{3} \mathrm{Cu} \mathrm{Lu}_{4}\right)$ & 42.3 & 1.6 & 55.0 & 0.3 & 0.7 & 0.0 \\
\hline
\end{tabular}

Fig. 7-The SEM BEIs and EPMA chemical analysis results of the infrared-brazed Ti-6Al-4V/72Ag-28Cu/Nb joint at $850{ }^{\circ} \mathrm{C}$ for $60 \mathrm{~s}$. 

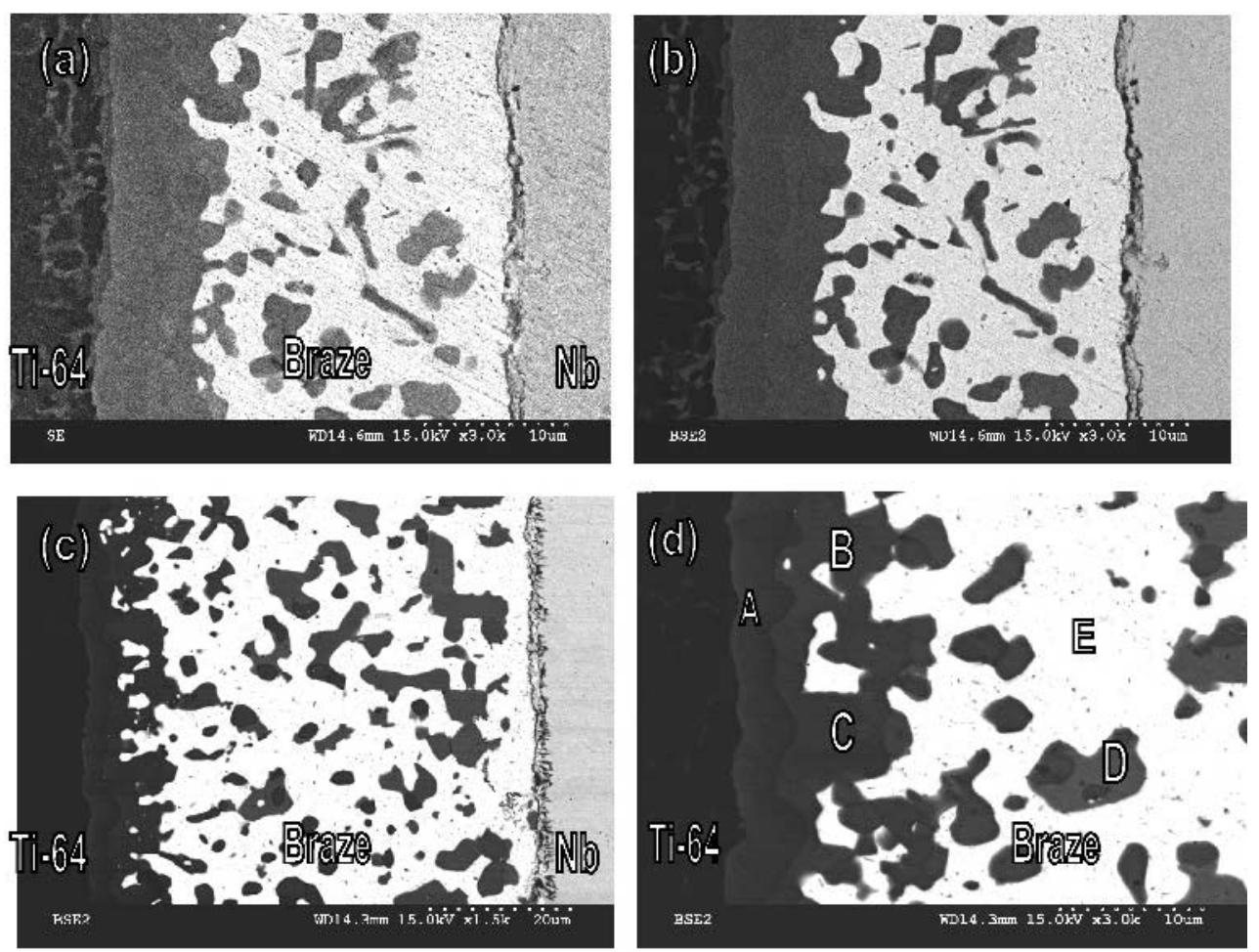

\begin{tabular}{ccccccc}
\hline Location (phasc) $/ \mathrm{at} \%$ & $\mathrm{Ti}$ & $\mathrm{Ag}$ & $\mathrm{Cu}$ & $\mathrm{Al}$ & $\mathrm{V}$ & $\mathrm{Nb}$ \\
\hline $\mathrm{A}(\mathrm{TiCu})$ & 49.8 & 2.9 & 45.5 & 1.0 & 0.9 & 0.0 \\
$\mathrm{~B}\left(\mathrm{Ti}_{3} \mathrm{Cu}_{4}\right)$ & 41.4 & 1.3 & 55.8 & 0.3 & 1.3 & 0.0 \\
$\mathrm{C}\left(\mathrm{Ti}_{3} \mathrm{Cu}_{4}\right)$ & 42.7 & 1.2 & 54.6 & 0.3 & 1.2 & 0.0 \\
$\mathrm{D}\left(\mathrm{Cu}-\mathrm{rich}^{2}\right)$ & 21.2 & 1.3 & 75.3 & 1.5 & 0.7 & 0.0 \\
$\mathrm{E}(\mathrm{Ag}-$ rich) & 0.4 & 87.5 & 11.0 & 1.0 & 0.0 & 0.1 \\
\hline
\end{tabular}

Fig. 8-The SEM images and EPMA chemical analysis results of the furnace-brazed specimens: $(a)$ SEI and $(b)$ BEI $\left(800{ }^{\circ} \mathrm{C} \times 600 \mathrm{~s}\right)$; and $(c)$ and (d) $\mathrm{BEI}\left(800{ }^{\circ} \mathrm{C} \times 1200 \mathrm{~s}\right)$.

distortion of $\mathrm{Ag}-\mathrm{Cu}$ eutectic braze due to high flow stress is also observed in Figure 10(a). For the specimen furnace brazed at $800{ }^{\circ} \mathrm{C}$, the joint is fractured along the braze alloy (Figures 10(b) and (c)). However, the fracture location changes from the braze alloy into the interfacial reaction layer for the specimen furnace brazed at $850{ }^{\circ} \mathrm{C}$, as shown in Figures 10(d) and (e). It is clear that the presence of thin $\mathrm{Cu}$-Ti reaction layer(s) has little effect on its shear strength. However, excessive growth of the interfacial $\mathrm{Cu}$-Ti reaction layer(s) is usually detrimental to the bonding strength of the brazed joint.

\section{Ti-6Al-4V/95Ag-5Al/Nb-Brazed Joint}

Figure 11 shows the dynamic wetting angle measurements of $95 \mathrm{Ag}-5 \mathrm{Al}$ and $92.6 \mathrm{Ag}-5 \mathrm{Al}-2.4 \mathrm{Ti}$ (wt pct) on the niobium substrate for various temperatures. According to Figure 11(a), the $95 \mathrm{Ag}-5 \mathrm{Al}$ braze alloy cannot wet the niobium substrate even increasing the test temperature from $850{ }^{\circ} \mathrm{C}$ to $950{ }^{\circ} \mathrm{C}$. On the other hand, 92.6Ag-5Al-2.4Ti can wet the niobium substrate as the test temperature increased from $850{ }^{\circ} \mathrm{C}$ to $950{ }^{\circ} \mathrm{C}$. It is also noted that the improvement of wettability on the niobium substrate for the $92.6 \mathrm{Ag}-5 \mathrm{Al}-2.4 \mathrm{Ti}$ braze alloy is not as effective as $97.6 \mathrm{Ag}-2.4 \mathrm{Ti}$ and $63 \mathrm{Ag}-35.25 \mathrm{Cu}-$ $1.75 \mathrm{Ti}$ braze alloys.
Figure 12 displays SEM images and EPMA chemical analysis results of the infrared-brazed Ti-6Al-4V/95Ag$5 \mathrm{Al} / \mathrm{Nb}$ joint at $950{ }^{\circ} \mathrm{C}$ for 60 seconds. The infrared-brazed joint is mainly composed of Ag-rich phase, as marked by "C" in Figure 12. The dissolution of Nb substrate is very limited based on the EPMA chemical analysis results. Additionally, the TiAl interfacial reaction layer between Ti-6Al$4 \mathrm{~V}$ and the braze alloy is observed, as marked by " $\mathrm{A}$ " and "B" in Figure 12. There is also an interfacial layer between the braze alloy and $\mathrm{Nb}$ substrate. However, it cannot be accurately analyzed due to its thickness below $1 \mu \mathrm{m}$.

Figure 13 illustrates the SEM images and chemical analysis results of the furnace-brazed Ti-6Al-4V/95Ag-5Al/Nb joint at $850{ }^{\circ} \mathrm{C}$ for 600 seconds. Similar to the previous infrared-brazed specimen, the brazed joint consists of Ag-rich and interfacial TiAl phases. The microstructure of furnacebrazed specimens is significantly changed as the brazing temperature increases from $850{ }^{\circ} \mathrm{C}$ to $900{ }^{\circ} \mathrm{C}$ (Figure 14). Both dissolution of Ti-6Al-4V substrate into the molten braze and interfacial reaction(s) are significantly enhanced. The amount of Ag-rich phase is greatly decreased, and the thickness of the interfacial reaction layer is increased. Because dissolution of the Ti-6Al-4V substrate is greatly increased, the interfacial reaction layer becomes $\mathrm{Ti}_{3} \mathrm{Al}$ instead of TiAl as marked by "A", "B", "D", and "E" in Figure 14. Additionally, further 

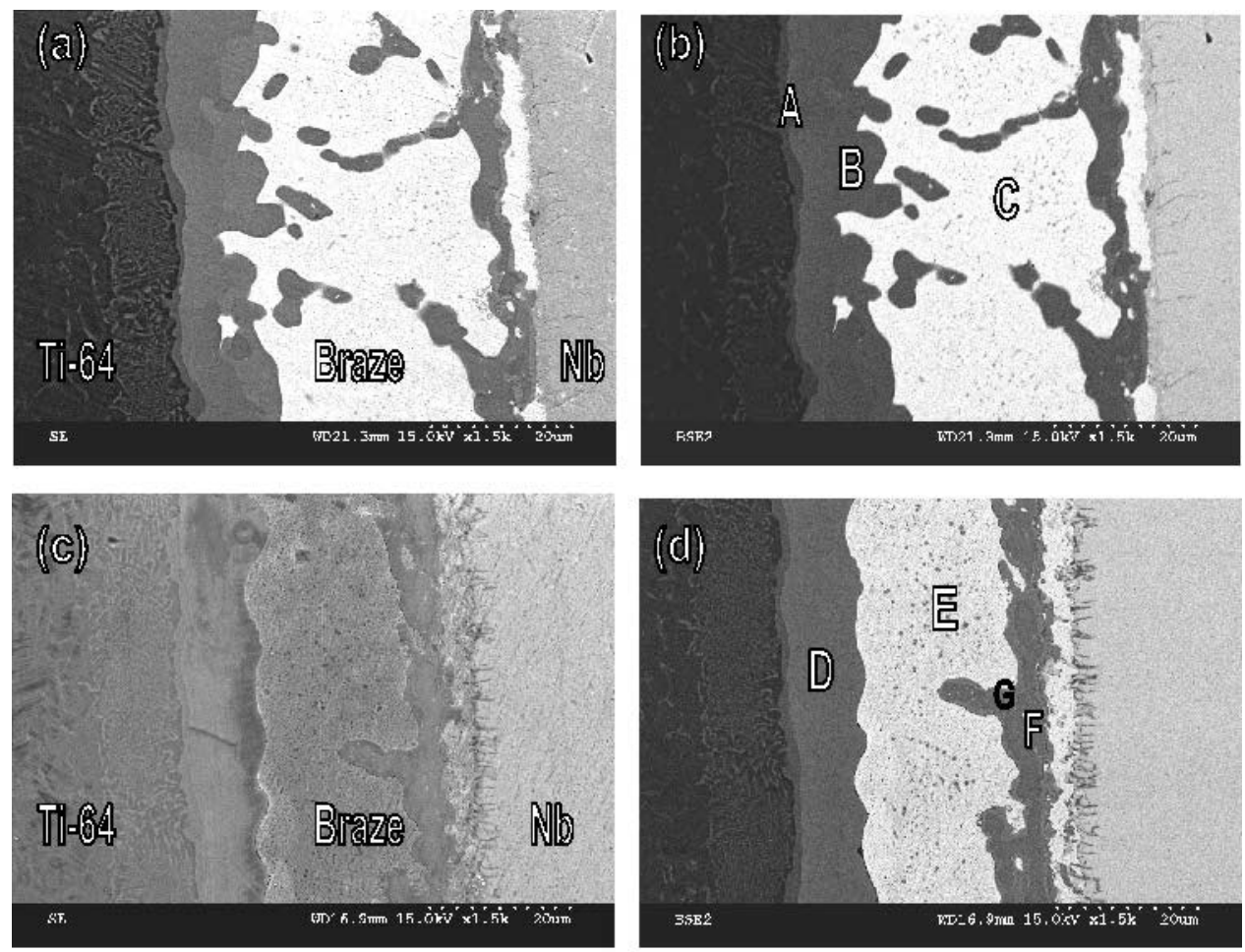

\begin{tabular}{ccccccc}
\hline Location (phase) $/ \mathrm{at} \%$ & $\mathrm{li}$ & $\mathrm{Ag}$ & $\mathrm{Cu}$ & $\mathrm{Al}$ & $\mathrm{V}$ & $\mathrm{Nb}$ \\
\hline $\mathrm{A}\left(\mathrm{Ti}{ }_{2} \mathrm{Cu}\right)$ & 65.2 & 1.7 & 29.0 & 3.3 & 0.9 & 0.0 \\
$\mathrm{~B}(\mathrm{TiCu})$ & 50.2 & 5.3 & 42.5 & 1.2 & 0.8 & 0.0 \\
$\mathrm{C}(\mathrm{Ag}-\mathrm{rich})$ & 0.6 & 94.9 & 2.7 & 1.7 & 0.0 & 0.1 \\
$\mathrm{D}(\mathrm{TiCu})$ & 49.5 & 2.8 & 46.2 & 0.7 & 0.8 & 0.0 \\
$\mathrm{~F}(\mathrm{Ag}-\mathrm{rich})$ & 0.4 & 82.3 & 14.8 & 2.3 & 0.2 & 0.0 \\
$\mathrm{~F}\left(\mathrm{Ii}_{3} \mathrm{Cu} \mathrm{Cu}_{4}\right)$ & 42.0 & 1.3 & 53.9 & 0.7 & 0.4 & 1.8 \\
$\mathrm{G}(\mathrm{Cu}-\mathrm{rich})$ & 17.4 & 1.3 & 77.1 & 1.0 & 0.6 & 2.6 \\
\hline
\end{tabular}

Fig. 9-The SEM images and EPMA chemical analysis results of the furnace-brazed specimens: $(a)$ SEI and $(b) \mathrm{BEI}\left(850{ }^{\circ} \mathrm{C} \times 600 \mathrm{~s}\right)$; and $(c)$ SEI, and (d) $\mathrm{BEI}\left(850^{\circ} \mathrm{C} \times 1200 \mathrm{~s}\right)$.

X-ray structural analysis will be performed in the following experiment.

Table II lists shear strengths of brazed Ti-6Al-4V/95Ag$5 \mathrm{Al} / \mathrm{Nb}$ joints. According to Table II, the average shear strength of the infrared-brazed specimen is $172.8 \mathrm{MPa}$. In contrast, the shear strength of the furnace-brazed joint cannot be obtained from the test due to its low bonding strength. Figure 15 displays the SEM cross section of Ti$6 \mathrm{Al}-4 \mathrm{~V} / 95 \mathrm{Ag}-5 \mathrm{Al} / \mathrm{Nb}$ joint after shear test. For the infraredbrazed specimen, the crack is located at the Ag-rich matrix. In contrast, the furnace-brazed specimen is fractured along the interfacial $\mathrm{Ti}_{3} \mathrm{Al}$ layer. It is reasonable to conclude that the coarsening of the $\mathrm{Ti}_{3} \mathrm{Al}$ reaction layer significantly deteriorates the bonding strength of the furnace-brazed joint.

Figure 16 shows the SEM fractographs and X-ray analysis of Ti-6Al-4V/95Ag-5Al/Nb joint after shear test. For the infrared-brazed joint, ductile dimple fracture is widely observed in the fractured surface (Figure 16(a)). This finding is consistent with the aforementioned microstructural observation. On the other hand, cleavage-dominated fracture is observed for the furnace-brazed specimen, as demonstrated in Figure 16(b). The characteristic X-ray peaks of
$\mathrm{Ti}_{3} \mathrm{Al}$ are also identified from the fractured surface of the furnace-brazed specimen. Accordingly, the existence of the inherently brittle $\mathrm{Ti}_{3} \mathrm{Al}$ reaction layer is detrimental to the shear strength of the brazed joint.

Based on this study, application of infrared brazing can effectively inhibit the interfacial reaction between the braze alloy and substrate due to its very rapid thermal cycle. Minimum erosion of the base metal is expected during infrared brazing. In contrast, the metallurgical reaction among the braze alloy and substrates is greatly enhanced for the furnace-brazed specimen due to its longer thermal history.

\section{CONCLUSIONS}

The brazing of Ti-6Al-4V and niobium metal using three silver-base braze alloys has been accessed in the experiment. The primary conclusions are summarized as follows.

1. According to the dynamic wetting angle measurement results, the niobium substrate cannot be effectively wetted by all three braze alloys. The dissolution of Ti-6Al$4 \mathrm{~V}$ substrate during brazing results in transport of Ti into 

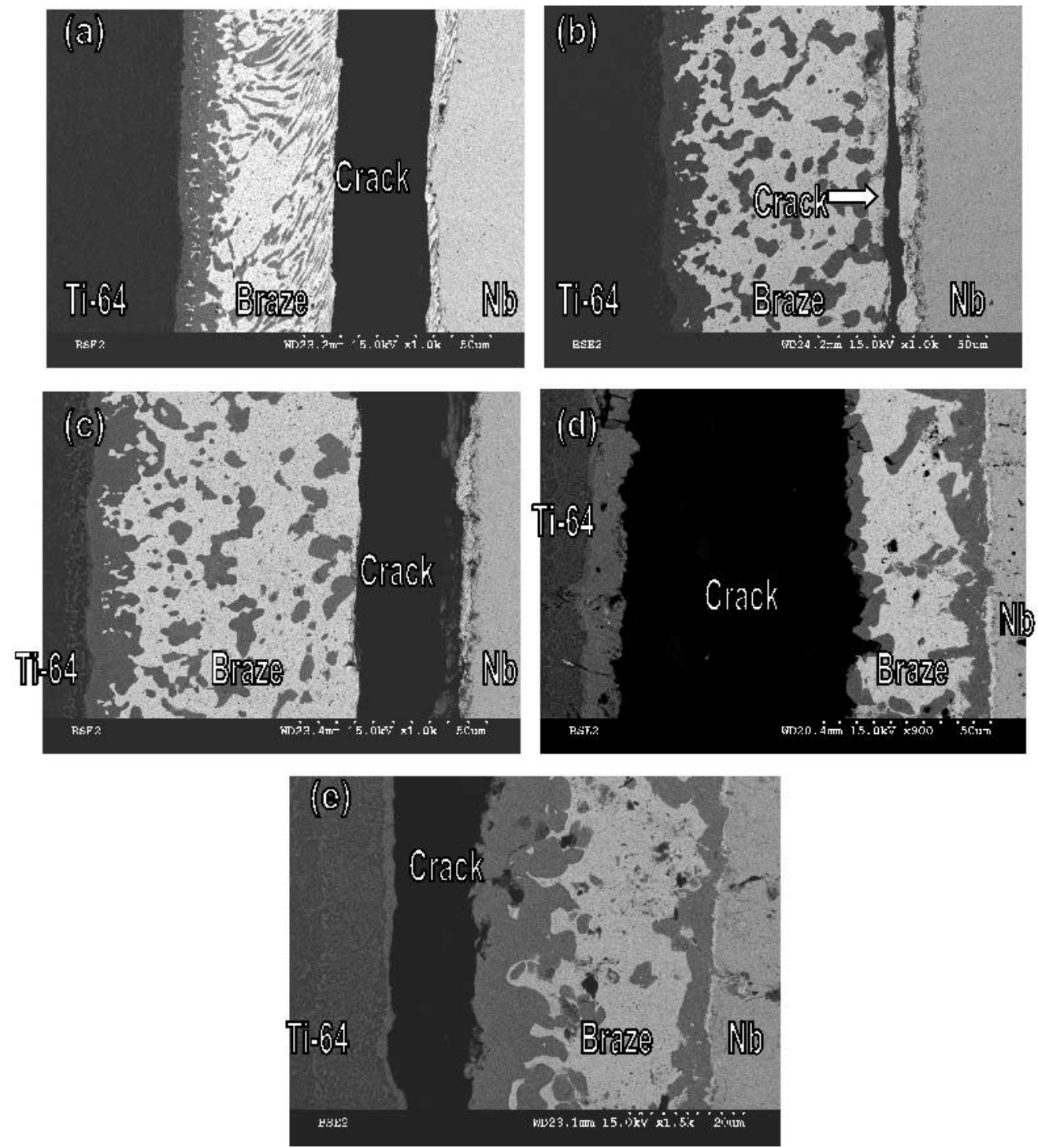

Fig. 10-SEM cross section of Ti-6Al-4V/72Ag-28Cu/Nb joint after shear test: $(a) 850{ }^{\circ} \mathrm{C} \times 60 \mathrm{~s}$ (infrared), $(b) 800{ }^{\circ} \mathrm{C} \times 600 \mathrm{~s}\left(\right.$ furnace), $(c) 800{ }^{\circ} \mathrm{C} \times$ $1200 \mathrm{~s}$ (furnace), $(d) 850{ }^{\circ} \mathrm{C} \times 600 \mathrm{~s}$ (furnace), and $(e) 850{ }^{\circ} \mathrm{C} \times 1200 \mathrm{~s}$ (furnace).

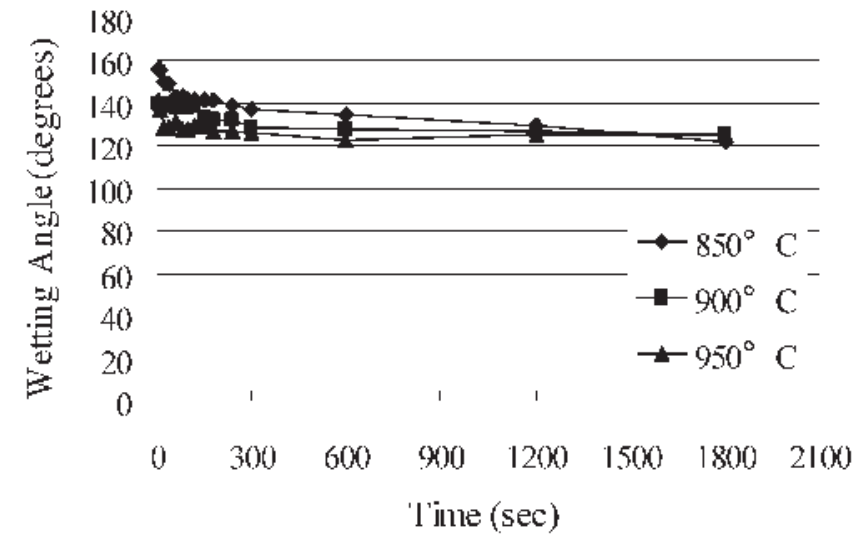

(a)

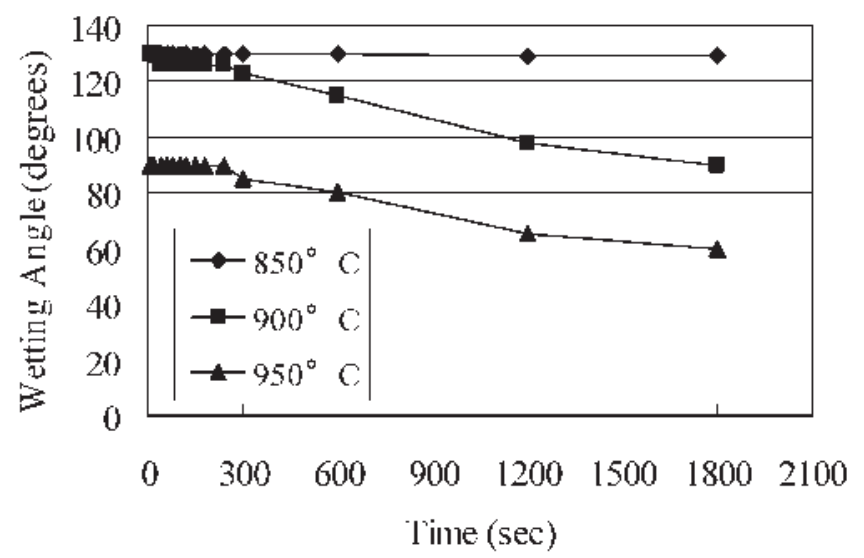

(b)

Fig. 11-The dynamic wetting angle measurements of (a) 95Ag-5 Al and (b) 92.6Ag-5Al-2.4Ti (wt pct) on the niobium substrate for various temperatures between 0 to $1800 \mathrm{~s}$. 

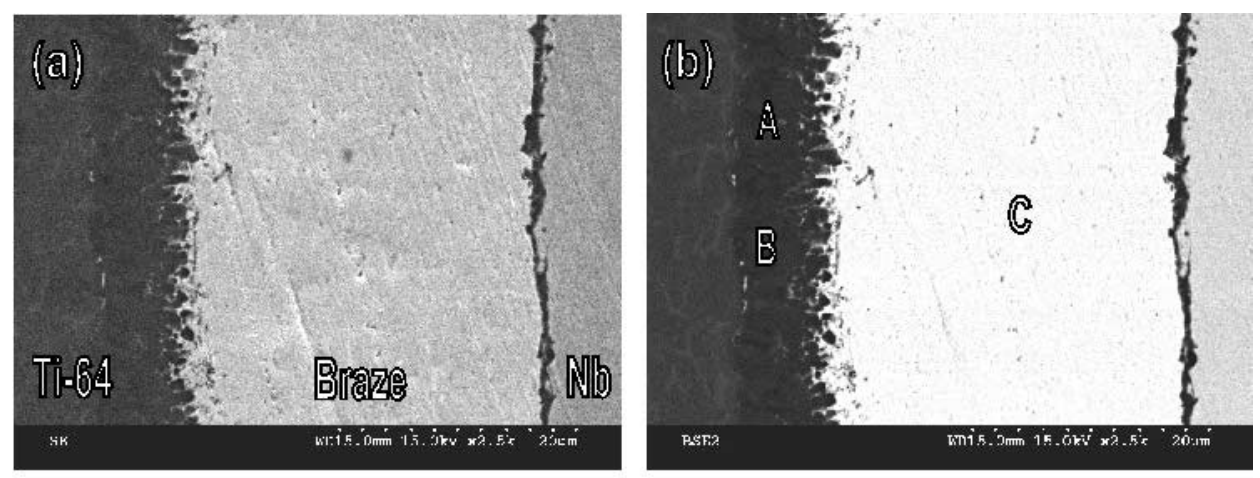

\begin{tabular}{cccccc}
\hline Location (phase) $/ \mathrm{al} \%$ & $\mathrm{Ti}$ & $\Lambda \mathrm{g}$ & $\Lambda 1$ & $\mathrm{~V}$ & $\mathrm{Nb}$ \\
\hline $\mathrm{A}(\mathrm{TiAl})$ & 50.9 & 3.8 & 43.4 & 1.8 & 0.0 \\
$\mathrm{~B}(\mathrm{TiAl})$ & 50.0 & 2.9 & 43.9 & 3.2 & 0.0 \\
$\mathrm{C}$ (Ag-rich) & 0.5 & 87.3 & 12.0 & 0.2 & 0.0 \\
\hline
\end{tabular}

Fig. 12-The SEM (a) SEI, (b) BEI, and EPMA chemical analysis results of the infrared-brazed Ti-6Al-4V/95Ag-5Al/Nb joint at $950{ }^{\circ} \mathrm{C}$ for $60 \mathrm{~s}$.
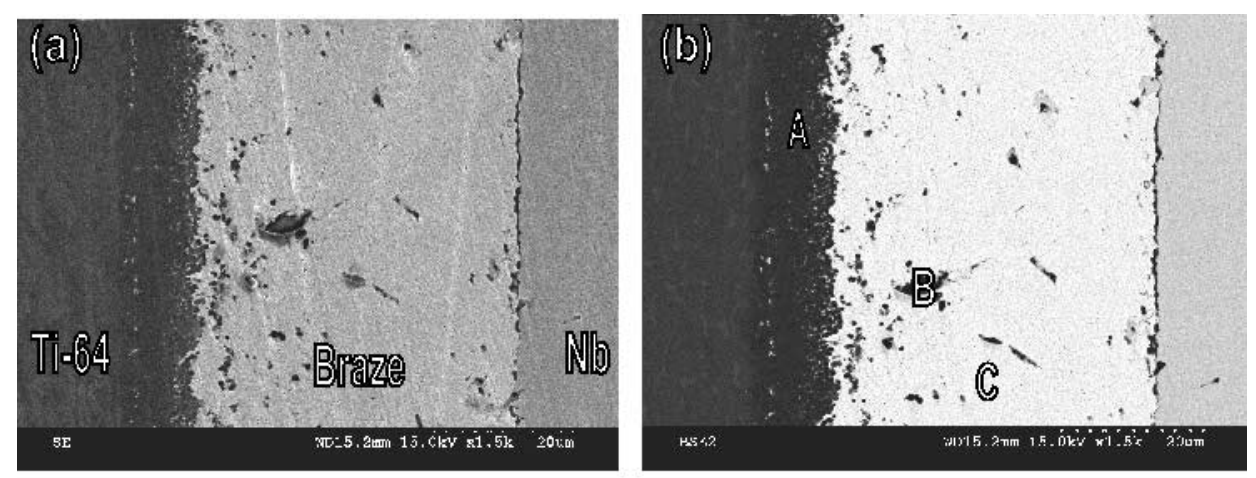

\begin{tabular}{cccccc}
\hline Location (phase) $/ \mathrm{al} \%$ & $\mathrm{Ti}$ & $\mathrm{Ag}$ & $\mathrm{Al}$ & $\mathrm{V}$ & $\mathrm{Nb}$ \\
\hline $\mathrm{A}(\mathrm{TiAl})$ & $5 \mathrm{~T} .5$ & 3.4 & 43.5 & 1.6 & 0.0 \\
$\mathrm{~B}(\mathrm{Ti} \mathrm{Al})$ & 48.0 & 8.3 & $4 \mathrm{I} .1$ & 2.6 & 0.0 \\
$\mathrm{C}(\Lambda \mathrm{g}$-rich) & $\mathrm{I} .4$ & 96.5 & 1.8 & 0.2 & 0.0 \\
\hline
\end{tabular}

Fig. 13-The SEM (a) SEI, (b) BEI, and EPMA chemical analysis results of the furnace-brazed Ti-6Al-4V/95Ag-5Al/Nb joint at $850{ }^{\circ} \mathrm{C}$ for $600 \mathrm{~s}$.
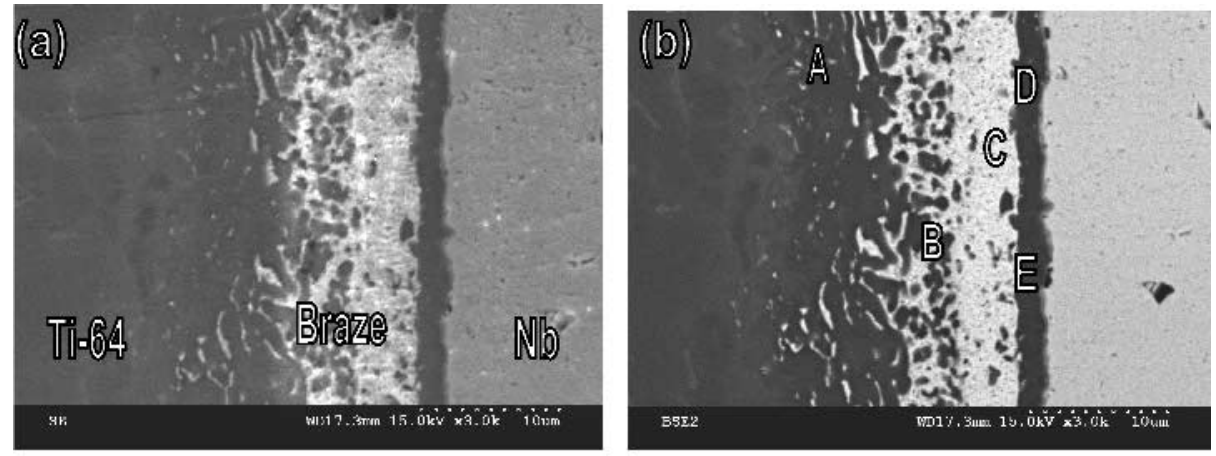

\begin{tabular}{cccccc}
\hline Location (phase) $/$ at $\%$ & $\mathrm{Ti}$ & $\mathrm{Ag}$ & $\mathrm{Al}$ & $\mathrm{V}$ & $\mathrm{Nb}$ \\
\hline$\Lambda\left(\mathrm{Ti}_{3} \wedge \mathrm{l}\right)$ & 71.6 & 1.4 & 24.2 & 2.7 & 0.0 \\
$\mathrm{~B}\left(\mathrm{Ti}_{3} \wedge \mathrm{l}\right)$ & 66.8 & 3.8 & 27.0 & 2.4 & 0.0 \\
$\mathrm{C}(\mathrm{Ag}-\mathrm{rich})$ & 1.4 & 96.5 & 1.8 & 0.2 & 0.0 \\
$\mathrm{D}\left(\mathrm{Ti}_{3} \mathrm{Al}\right)$ & 70.8 & 1.1 & 26.1 & 1.9 & 0.0 \\
$\mathrm{E}\left(\mathrm{Ti}_{3} \mathrm{Al}\right)$ & 68.6 & 2.7 & 25.4 & 2.2 & 1.2 \\
\hline
\end{tabular}

Fig. 14-The SEM (a) SEI, (b) BEI, and EPMA chemical analysis results of the furnace-brazed Ti-6Al-4V/95Ag-5 Al/Nb joint at $900{ }^{\circ} \mathrm{C}$ for $600 \mathrm{~s}$. 

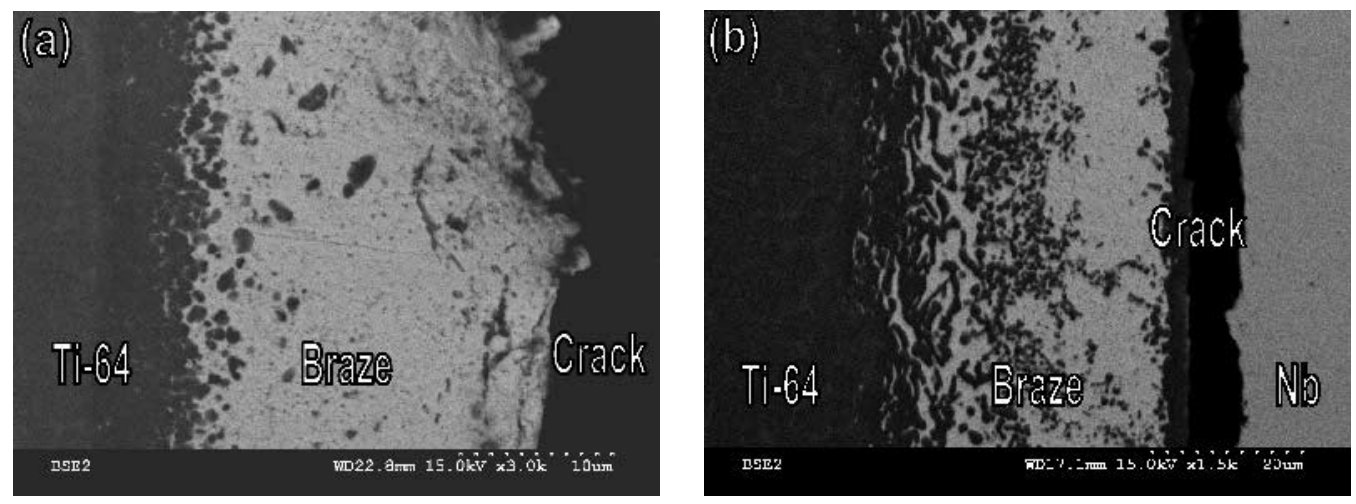

Fig. 15-SEM cross section of the Ti-6Al-4V/95Ag-5Al/Nb joint after shear test: $(a) 950{ }^{\circ} \mathrm{C} \times 60 \mathrm{~s}$ (infrared brazing), and $(b) 900{ }^{\circ} \mathrm{C} \times 1200 \mathrm{~s}$ (furnace brazing).
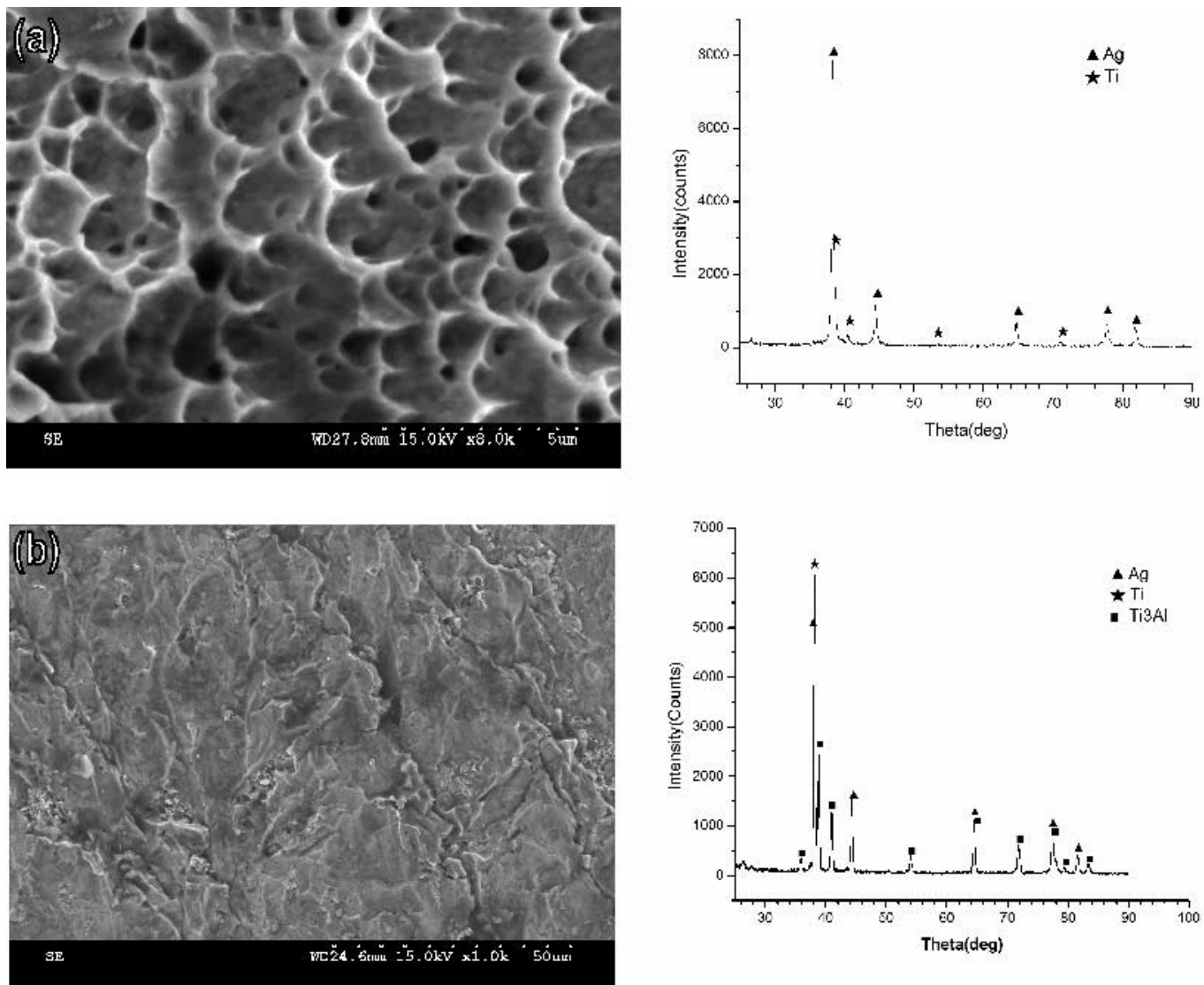

Fig. 16-SEM fractographs and X-ray analysis of Ti-6Al-4V/95Ag-5Al/Nb joint after shear test: $(a) 950{ }^{\circ} \mathrm{C} \times 60 \mathrm{~s}$ (infrared brazing) and $(b) 900{ }^{\circ} \mathrm{C} \times$ $1200 \mathrm{~s}$ (furnace brazing).

the molten braze, so the molten braze can effectively wet the niobium substrate during brazing.

2. The infrared-brazed Ti-6Al-4V/Ag/Nb joint is mainly comprised of Ag-rich matrix. The TiAg reaction layer at the interface between the braze alloy and Ti-6Al-4V substrate is also observed. With increasing the brazing temperature or time, the dissolution of the Ti-6Al-4V substrate into the molten braze is greatly enhanced, and the Ti-rich phase dominates the furnace-brazed joint.

3 . The average shear strength of the infrared-brazed Ti-6Al$4 \mathrm{~V} / \mathrm{Ag} / \mathrm{Nb}$ joint is $173.0 \mathrm{MPa}$, and it is much higher than that of the furnace-brazed one $(117.5 \mathrm{MPa})$. For the infrared-brazed specimen, the crack propagates along the Ag-rich matrix. In contrast, the furnace-brazed specimen is fractured primarily along the Ti-rich phase. The presence of shrinkage porosity in the furnace-brazed specimen deteriorates its joint strength.

4. The infrared-brazed Ti-6Al-4V/72Ag-28Cu/Nb joint is mainly comprised of the Ag-rich matrix and $\mathrm{Ag}-\mathrm{Cu}$ eutectic. With increasing the brazing temperature or time, the amount of $\mathrm{Ag}-\mathrm{Cu}$ eutectic is greatly decreased and the interfacial $\mathrm{Cu}-\mathrm{Ti}$ reaction layer(s) is increased.

5. The infrared-brazed Ti-6Al-4V/72Ag-28Cu/Nb specimen has the highest average shear strength of $224.1 \mathrm{MPa}$ among 
all specimens. The average shear strength is decreased with increasing brazing temperature or time. Both the infraredbrazed specimen and $800{ }^{\circ} \mathrm{C}$ furnace-brazed specimen are fractured at the braze alloy. In contrast, the fracture location changes from the braze alloy into the interfacial reaction layer for the specimen furnace brazed at $850{ }^{\circ} \mathrm{C}$ due to excessive growth of the interfacial $\mathrm{Cu}$-Ti reaction layer(s).

6. The Ti-6Al-4V/95Ag-5Al/Nb joint infrared brazed at $950{ }^{\circ} \mathrm{C}$ for 60 seconds is mainly composed of Ag-rich matrix and $\mathrm{TiAl}$ interfacial reaction layer. With increasing the brazing time, the amount of Ag-rich phase is greatly decreased, and the thickness of the interfacial reaction layer is increased. Because dissolution of the Ti-6Al-4V substrate is greatly enhanced for longer brazing times, the interfacial reaction layer becomes $\mathrm{Ti}_{3} \mathrm{Al}$ instead of $\mathrm{TiAl}$ for the furnace-brazed specimen above $900{ }^{\circ} \mathrm{C}$.

7. The average shear strength of the infrared-brazed Ti-6Al$4 \mathrm{~V} / 95 \mathrm{Ag}-5 \mathrm{Al} / \mathrm{Nb}$ joint is $172.8 \mathrm{MPa}$. In contrast, the shear strength of the furnace-brazed joint cannot be obtained from the test due to its low bonding strength. The existence of the $\mathrm{Ti}_{3} \mathrm{Al}$ reaction layer significantly deteriorates the bonding strength of the furnace-brazed joint.

\section{ACKNOWLEDGMENTS}

The authors gratefully acknowledge the financial support of this study by the National Science Council (NSC), Republic of China, under NSC Grant Nos. 92-2216-E-259001 and 93-2216-E-002-028. The EPMA analyses by Ms. Shu-Yueh Tsai, NSC Instrument Center, National Tsing Hua University (Hsinchu, Taiwan), are also highly appreciated.

\section{REFERENCES}

1. R. Roger, E.W. Collings, and G. Welsch: Materials Properties Handbook: Titanium Alloys, ASM INTERNATIONAL, Materials Park, OH, 1993.

2. Metals Handbook, vol. 2, Properties and Selection: Nonferrous Alloys and Special Purpose Materials, J.R. Davis, ed., ASM INTERNATIONAL, Materials Park, OH, 1990.
3. ASM Handbook, vol. 6, Welding, Brazing and Soldering, D.L. Olson, I.A. Siewert, S. Liu, and G.R. Edwards, eds., ASM INTERNATIONAL, Materials Park, OH, 1993.

4. W.F. Smith: Structure and Properties of Engineering Alloys, McGarwHill Inc., New York, NY, 1993.

5. M. Schwartz: Brazing: for the Engineering Technologist, ASM INTERNATIONAL, Materials Park, OH, 1995.

6. M. Schwartz: Brazing, ASM INTERNATIONAL, Metals Park, OH, 1987.

7. G. Humpston and D.M. Jacobson: Principles of Soldering and Brazing, ASM INTERNATIONAL, Materials Park, OH, 1993.

8. N.A. Dececco and J.N. Parks: Welding J., 1953, vol. 32 (11), pp. 1071-81.

9. C.C. Liu, C.L. Ou, and R.K. Shiue: J. Mater. Sci., 2002, vol. 37 (11), pp. 2225-35.

10. T. Takemoto and I. Okamoto: J. Mater. Sci., 1988, vol. 23 (4), pp. 1301-08.

11. D.G. Howden and R.W. Monroe: Welding J., 1972, vol. 51 (1), pp. 31-36.

12. R.K. Shiue, S.K. Wu, and S.Y. Chen: Acta Mater., 2003, vol. 51 (7), pp. 1991-2004.

13. S.W. Lan: Welding J., 1982, vol. 61 (10), pp. 23-28.

14. O. Botstein and A. Rabinkin: Mater. Sci. Eng. A., 1994, vol. A188, pp. 305-15.

15. O. Botstein, A. Schwarzman, and A. Rabinkin, Mater. Sci. Eng. A, 1996, vol. A206, pp. 14-23.

16. H.Y. Chan and R.K. Shiue: J. Mater. Sci. Lett., 2003, vol. 22 (23), pp. 1659-63.

17. H.Y. Chan, D.W. Liaw, and R.K. Shiue: Int. J. Refract. Met. Hard Mater., 2004, vol. 22, pp. 27-33.

18. H.Y. Chan, D.W. Liaw, and R.K. Shiue: Mater. Lett., 2004, vol. 58, pp. 1141-46.

19. R.K. Shiue, S.K. Wu, J.M.O and J.Y. Wang: Metall. Mater. Trans. A, 2000, vol. 31A, pp. 2527-36.

20. Y.L. Lee, R.K. Shiue, and S.K. Wu: Intermetallics, 2003, vol. 11 (3), pp. $187-95$.

21. R.K. Shiue, S.K. Wu, and C.M. Hung: Metall. Mater. Trans. A, 2002, vol. 33A, pp. 1765-73.

22. R.K. Shine, S.K. Wu, and C.H. Chan: J. Alloy Compounds, 2004, vol. 372 , pp. $148-57$.

23. C.C. Lin, R.B. Chen, and R.K. Shine: J. Mater. Sci., 2001, vol. 36 (9), pp. 2145-50.

24. T.B. Massalski: Binary Alloy Phase Diagrams, ASM INTERNATIONAL, Materials Park, OH, 1990.

25. P. Villars, A. Prince, and H. Okamoto: Handbook of Ternary Alloy Phase Diagrams, ASM INTERNATIONAL, Materials Park, OH, 1995. 